Dr. Gunther describes in his lecture both the collections of books and geological material left by Daubeny and of which he took charge, and also how for many years he continued the scientific work of Daubeny in measuring the sea- and land-levels all round the Italian coast. Daubeny, though a man of varied scientific interests, had made a special study of volcanic phenomena in Europe, above all in France and Italy. He represented the universities of England at the first meeting of the British Association at York in 1831, and through his influence the second meeting was held in Oxford.

Dr. Gunther has done well to keepDaubeny's memory alive in his old university, and the opportunity now seems to have arrived to give better housing, both for the Daubeny collections and library and also for the Lewis Evans collection of scientific instruments which have been left to Oxford, and are at present exhibited in a portion of the Old Ashmolean building. It is difficult for a non-resident to appreciate all the conditions of building in present-day Oxford. We know that the Bodleian is now embarking on a large scheme of reconstruction. It is known also that the Radcliffe Trustees have recently opened a new and beautiful building. There is also, it seems, additional accommodation available in the Ashmolean for the objects which Dr. Gunther desires to preserve.

The building question is therefore complicated, but every friend of science will heartily support Dr. Gunther in his claim that the history of science should be duly represented in the university which has so many men of science on its rolls. An obvious and indispensable way of doing this is to have a good library of books on this branch of knowledge, available for all serious students. If this can be done in conjunction with a museum of scientific instruments and objects, such as those which Dr. Gunther has in charge, it would, of course, have added value.

\section{Electrical Warming of Large Buildings}

$\mathrm{I}^{\mathrm{N}}$ a lengthy paper read to the Institution of Electrical Engineers on December 6, Mr. R. Grierson and Mr. D. Betts make a critical examination of the present practice relating to electrical warming, air-conditioning and hot water supply to large buildings.

It is often assumed that before electric heating can be justified as compared with a coke-fired boiler and hot water or steam radiators, electricity must be sold at $0 \cdot 1 d$. per kilowatt hour. The assumption is made, that so long as $0 \cdot \mathrm{l} d$. purchases 3,410 British Thermal Units either from some form of electric radiator or from hot pipes, it is of equal value to the consumer. No account is taken of the practical elimination of the labour, dust and dirt effected by the electrical method. The fact also is disregarded that the householder has to pay $37 s .6 d .-75 s$. per ton of coal in the London area, whereas the fuel clause in the contracts of the Central Electricity Board are based on prices lying between 13s. and 18s, a ton. It is only necessary to recall the wonderful visibility of the atmosphere prevailing during the general strike of 1926 to see what a boon it would be to city dwellers if the volume of combustion products from chimneys were diminished.

It is now generally recognised that the question of the heat insulation of buildings is of great importance, and so slab cork and slag wool are being used to diminish the heat leakage. Thermostatic control is now largely used to prevent rooms from being overheated. Although the thermostat is a very trustworthy device, it is the standard practice in heating installations where the water is heated electrically to provide two instruments in series. One of them, the control thermostat, operates at the normal maximum temperature, while the other, called the safety thermostat, is set several degrees higher. A margin of $20^{\circ} \mathrm{F}$. below the boiling point of water is set for the control instrument and $10^{\circ} \mathrm{F}$. below boiling point for the other. Luckily, the 'ageing' of thermostats is in the direction of lowering the operating point.

The universal use of filtering plant for the continuous purification of swimming pools, instead of changing the water twice a week, has greatly simplified the heating problem. Formerly, the problem was to warm very large quantities of water in the least possible time ; now it is merely to prevent the water from cooling.

Air-conditioning plant has now been greatly improved. The air enters the room at a given temperature and humidity and the vitiated air is extracted. The minimum standard adopted by the London County Council is 1,000 cubic feet of fresh air per hour per person for music and dance halls. In winter, this amount is quite satisfactory; but in summer the temperature rises too high and so the fans are driven at a higher speed, often giving more than 2,000 cubic feet of air per hour per person. For cooling, powerful refrigerating plant is sometimes used. A 265 h.p. motor is installed for this purpose at the Masonic Peace Memorial Building in London.

\section{University and Educational Intelligence}

Cambridge.-The Arnold Gerstenberg studentship, founded in 1892 by Mrs. Leonora Phillips in memory of her brother Arnold Gerstenberg with the object of promoting the study of moral philosophy and metaphysics among students of natural science both men and women, has been awarded to R. C. Oldfield, of Peterhouse.

F. Goldby, of Queens' College, has been appointed University lecturer in anatomy, and H. W. Hull University demonstrator in anatomy.

Applications are invited for the Gwynaeth Pretty studentship for research in the etiology, pathology and treatment of disease. It is of the annual value of $£ 200$. Applications should reach Prof. H. R. Dean, Department of Pathology, before February 1.

OxFord.--On December 1, Dr. R. T. Gunther continued his series of public lectures on the history of science in Oxford by a discourse delivered at Corpus Christi College. Remarking that the contribution to natural science by members of that College made up in quality what was lacking in quantity, he directed special attention to Nicholas Kratzer, who became a fellow of the College in 1517, the year of its foundation. In Kratzer's hands the development took place of the mural and pedestal sundial to such portable dials as the polyhedral timepiece made by him for Cardinal Wolsey, by whom he was constituted mathematical reader in the University. Thomas Hornsby, who succeeded Bradley as Savilian professor in 1762 , was mainly 